\title{
Laboreal
}

Volume $5 \mathrm{~N}^{\circ} 2$ | 2009

Varia

\section{A automobilização de uma teleatendente para enfrentar as adversidades do trabalho em um Call \\ Center}

La automovilización de una teleatendiente para enfrentar las adversidades del

trabajo en un Call Center

L'automobilisation d'une opératrice face à des situations de travail adverses

dans un Centre d'appel

The automobilisation of a telephone operator to face the hardships of working in a call center

Marcello Santos Rezende, Jussara Brito e Milton Athayde

\section{(2) OpenEdition}

\section{Journals}

\section{Edição electrónica}

URL: http://journals.openedition.org/laboreal/9809

ISSN: 1646-5237

\section{Editora}

Universidade do Porto

\section{Refêrencia eletrónica}

Marcello Santos Rezende, Jussara Brito e Milton Athayde, «A automobilização de uma teleatendente para enfrentar as adversidades do trabalho em um Call Center », Laboreal [Online], Volume 5 No$^{\circ} 2$ | 2009, posto online no dia 01 dezembro 2009, consultado o 10 outubro 2019. URL : http:// journals.openedition.org/laboreal/9809

Este documento foi criado de forma automática no dia 10 outubro 2019.

Laboreal está licenciado com uma Licença Creative Commons - Atribuição-NãoComercial 4.0 Internacional. 


\title{
A automobilização de uma teleatendente para enfrentar as adversidades do trabalho em um Call Center
}

\author{
La automovilización de una teleatendiente para enfrentar las adversidades del \\ trabajo en un Call Center \\ L'automobilisation d'une opératrice face à des situations de travail adverses \\ dans un Centre d'appel \\ The automobilisation of a telephone operator to face the hardships of working in \\ a call center
}

Marcello Santos Rezende, Jussara Brito e Milton Athayde

\section{NOTA DO EDITOR}

Manuscrito recebido em : Maio/2009

Aceite após peritagem : Setembro/2009

\section{Introdução}

1 O call center, definido por Gallais (1999) como uma entidade composta de grupos de operadores organizados para receber ou emitir chamadas telefônicas em massa, é o local onde são efetuados os principais serviços de telemarketing. Originados de uma aliança de numerosas mudanças tecnológicas, os call centers são baseados em um mesmo princípio: a integração de tecnologias de informática e do telefone (CTI, sigla internacional que significa Computer Telephony Integration) com o objetivo de responder em tempo real às demandas dos clientes. Envolve a utilização adequada e no mais alto 
grau dos recursos de administração da informação e de comunicações - telefonia, fax, correio de voz, internet e outros. 0 termo call center, proveniente da língua inglesa, popularizou-se bastante e é muito utilizado em outras línguas sem ser traduzido. No Brasil tem sido também usada a expressão "central de atendimento".

O mercado mundial de call center arrecadou cerca de 23 bilhões de euros em 1998, com estimativas de $€ 60$ bilhões em 2003, empregando cerca de 1,5 milhão de europeus e 5 milhões de pessoas nos Estados Unidos. 0 número de operadores nesse país pode variar de 2 a 7 milhões, trabalhando em 70 mil estabelecimentos (Marinho-Silva, 2004). Na Alemanha, são 65 mil trabalhadores e, na Austrália, os números chegam a $60 \mathrm{mil}$ (Toomingas et al., 2002). O call center é um dos negócios em maior desenvolvimento na Suécia, empregando $1,5 \%$ da população, contrastando com a cifra de 438 trabalhadores em 1987 (Norman, 2005, apud Assunção et al., 2006). No Reino Unido, estima-se que 860 mil pessoas trabalhem nas centrais de atendimento do Reino Unido (UNISON, 2005, apud Assunção et al., 2006) e outras 45 mil, na Espanha (UGT, 2005 apud Assunção et al., 2006). A estimativa no caso da Índia é de que emprega 813.500 trabalhadores, à medida que avanços tecnológicos têm permitido a mobilização de centros de atendimento das empresas globais para países com menores custos operacionais (UNI-ASIA \& PACIFIC, 2004, apud Assunção et al., 2006).

3 No Brasil, o mercado de call center ganhou impulso no final dos anos 80 e hoje é cada vez mais difundido nos mais diversos setores da economia. Os dados brasileiros, apesar de controversos e escassos, não diferem quanto à constatação de forte expansão e de importância econômica. Segundo a Associação Brasileira de Telesserviços (ABT), registraram-se 600 mil empregos diretos em 2005, com crescimento de $235 \%$ em três anos, revelando-se o maior empregador na área de serviços (ABT, 2006).

4 Ao lado dessa pujança econômica encontra-se uma outra realidade, paradoxal. Instituições de pesquisa e sindicatos de diversos países da Europa (Alemanha, Bélgica, Itália, França, Inglaterra e outros) criaram em 1999 um "Quadro de observação social dos call centers" que demonstrou ter-se tornado esse tipo de organização sinônimo de uma forma moderna de degradação das condições de trabalho e baixa proteção jurídica dos trabalhadores. Estresse, baixas remunerações e precarização da força de trabalho são algumas das palavras-chave ligadas a esse setor (Buscatto, 2002).

5 De modo geral, as centrais de atendimento são submetidas a uma medida muito precisa e intensa da produtividade que vem favorecendo o aparecimento de diversos problemas de saúde para seus operadores, como : disfonias vocais e auditivas, lesões por esforços repetitivos e sofrimento mental, como evidenciado em diversos estudos (MTE, 2005). Dado o quadro de desgaste dos operadores, entendemos que não se poderia falar em alta produtividade, caso a entendamos como uma relação inversamente proporcional entre quantidade de energia investida e quantidade de produtos/serviços gerados.

6 Portanto, as condições adversas de trabalho no setor de telemarketing, envolvendo problemas relativos à organização prescrita do trabalho, exigem estudos de diversos tipos e enfoques. A contribuição que pretendemos aqui apresentar é a de identificar as formas de automobilização, as estratégias criadas pelos operadores para lidarem com essas situações, na perspectiva de detectar problemas que eles tentam "driblar"/ contornar ou evitar, algo dificilmente reconhecível por observadores externos. Os saberes assim desenvolvidos pelos trabalhadores são muitas vezes "invisíveis" não só para os responsáveis formais pela organização do trabalho, mas também para os próprios trabalhadores - que os engendram em grande parte de forma não consciente. 
7 Em nosso enfoque privilegiamos o caráter situado do trabalho e a experiência concreta dos protagonistas do trabalho em foco. Interessamo-nos pela relação que eles estabelecem com o meio de trabalho, buscando em alguma medida recentrá-lo como seu meio (Canguilhem, 2001; Schwartz, 2000b), visando obter uma compreensão que propicie o engendramento de ações mais eficazes de prevenção e promoção da saúde. Pensamos que este caminho é coerente com a proposta de promoção da saúde a partir das situações de trabalho (Silva, Brito, Neves \& Athayde, 2009).

\section{Estudos acerca da relação saúde-trabalho das teletendentes}

8 Em nossa pesquisa bibliográfica sobre os estudos que articulavam a relação saúde e trabalho de teleatendentes/operadores de telemarketing. Uma primeira fonte foi o clássico artigo de Le Guillant (1956/1984) intitulado "A neurose das telefonistas". O próprio autor nos apresenta uma revisão bibliográfica sobre os estudos até então publicados sobre o tema, na França. Nossa busca foi efetuada em duas bases de dados eletrônicas : uma de teses e dissertações e outra de publicações periódicas, partindo-se das palavras-chave "teleatendimento", "telemarkeing" e "Call center". A primeira base utilizada foi o Banco de Teses da Coordenação de Aperfeiçoamento de Pessoal de Nível Superior - CAPES/Ministério da Educação (www.capes.gov.br). Um segundo banco de dados utilizado foi o SciELO - Scientific Electronic Library Online - uma biblioteca eletrônica que abrange uma coleção selecionada de periódicos científicos Latinoamericanos. Apresentamos a seguir parte do resultado analítico desse levantamento. .

9 Em 1910, o pesquisador Juliard (apud Le Guillant et al., 1956/1984), escreveu para a Revista Suíça de Acidentes de Trabalho que a atividade de trabalho das telefonistas era "enervante", em função da demanda de uma grande "tensão do espírito", acrescida da fadiga, da sobrecarga, da tensão nervosa e do efeito de receber observações injustas, muitas vezes grosseiras dos clientes. O autor considerava este quadro propício a produzir, em sujeitos predispostos, verdadeiras neuroses, que deveriam ser consideradas como doenças profissionais

10 Este mesmo quadro foi citado e reapresentado em 1918 por outros autores suíços, Fontègue e Solari (apud Le Guillant et al., 1956/1984), no estudo "Le Travail de la Téléphoniste", no qual foi ressaltada a importância dos sinais de fadiga associados a esta profissão, a saber: cefaléias, insônia, dificuldade de refletir e fixar a atenção, humor por vezes massacrante e "enervamento" violento, síndrome descrita pelos autores como "Neurose das Telefonistas".

11 Em 1949, Pacaud (apud Le Guillant et al., 1956/1984) publicou seu estudo "Pesquisas sobre trabalho das telefonistas : Estudo psicológico de um ofício", no qual realizou uma análise precisa dos mecanismos da fadiga nervosa, caracterizando o trabalho como penoso, desencadeador de fadiga e de freqüentes manifestações de nervosismo.

Em 1956, Le Guillant et al. (1956/1984) retomaram a pesquisa sobre a Neurose das Telefonistas, e apontaram como motivos para o desenvolvimento deste estudo as características das condições de trabalho que o progresso tecnológico tendia a instaurar pouco a pouco no setor de serviços. Estas condições foram definidas a partir da diminuição, pelo menos relativa, dos gastos energéticos musculares; da aceleração correlativa da velocidade das ações do trabalho e das cadências e, ainda, do acréscimo considerável dos esforços de atenção, precisão e rapidez. 
13 Torres (2001) afirma que na década de 1960, o estudo de Guilbert (1967, apud Torres, 2001) sobre as repercussões do trabalho na vida quotidiana das atendentes de informações telefônicas ressaltou a grande necessidade de repouso que as mesmas necessitavam. Muitas dormiam durante o trajeto de volta para casa e, assim, recuperavam uma certa calma para desempenhar as atividades do lar. As que não tinham a mesma oportunidade, sofriam as conseqüências e passavam o resto do dia tentando evitar um acréscimo de fadiga.

14 O componente "pressão temporal" apontado em 1956 por Le Guillant sobre a atividade das telefonistas é retomado por diversos estudiosos na década de 1970. A preocupação constante com o tempo de realização da tarefa se fazia presente de tal forma durante a execução da atividade, a ponto de ser referência para a avaliação de outros elementos do trabalho. Esta preocupação com o tempo cronológico podia ser observada nas diferentes modalidades de aplicação das cadências, no ritmo de trabalho, que determinava o grau de domínio do operador sobre a intensidade de sua atividade (Torres, 2001).

15 Ao final dos anos 80, as inovações tecnológicas introduzidas no call center, como o sistema de fila automática (o próprio computador faz as ligações ou recebe-as automaticamente), produziram grandes mudanças nas atividades dos operadores: maior intensificação do trabalho, menores níveis de autonomia e de apoio social de colegas (Balka, 1995).

16 Para Santos (2004), a intensificação do trabalho e os tempos reduzidos de atendimento nos call centers provocam a execução de dupla ou tripla atividade simultânea pelos atendentes (falar, digitar e "navegar" entre as diferentes janelas dos programas). A forte mobilização cognitiva está ligada à rigidez postural e aos riscos de doenças ocupacionais. $O$ autor afirma que estamos diante de uma nova taylorização do setor terciário, onde se prega o forte controle médio do atendimento, impondo aos trabalhadores grandes exigências mentais e psíquicas.

17 Outras pesquisas realizadas na França (Departamento de Ergologia da Universidade de Provence) demonstram que as empresas de teleatendimento daquele país apresentam aspectos de um trabalho "taylorizado" típico do mundo da indústria tradicional: ausência de controle do fluxo de trabalho (chamadas), cadências e produtividade fixadas por normas estritas (tempo de atendimento da chamada, tempo de pausa e outros), controle qualitativo das chamadas através de escutas (gravadas e on-line) e ausência de autonomia (Di Ruzza \& Franciosi, 2002). Ao lado disso ocorre uma separação muito rígida entre o trabalho de concepção e o trabalho de execução, onde o primeiro impõe uma relativa standartização da produção: as trocas verbais devem seguir os scripts pré-definidos pela gerência. Ainda segundo Di Ruzza, os call centers também podem ser considerados como lugares de recomposição das relações trabalhistas, no sentido de uma desmontagem das barreiras de proteção legais que têm sido progressivamente desrespeitadas : banalização do trabalho do fim-de-semana, do trabalho noturno, de horários atípicos, bem como do abuso de horários moduláveis.

No Brasil, Fernandes, Di Pace e Passos (2002) realizaram um estudo em uma empresa que atua no ramo de telemarketing, localizada na região metropolitana da cidade de Salvador, no estado da Bahia. Procuraram investigar o processo de trabalho do operador de telemarketing, sua natureza e organização, além de avaliar as repercussões desses fatores na saúde psíquica dos trabalhadores envolvidos. Realizaram observações do processo de trabalho, e em seguida, efetuou-se a coleta de dados na própria empresa 
através da aplicação de um questionário auto-aplicado em grupos de operadores. Participaram do estudo 155 operadores de um quadro total de 380. Para a caracterização da saúde psíquica e o nível de estresse psicológico dos trabalhadores utilizaram o General Health Questionnaire - GHQ 12. As principais queixas de saúde foram: problemas respiratórios, alergias e casos de LER. Diante dos resultados encontrados no estudo, observaram que a avaliação do estresse psíquico, obtida a partir da aplicação do GHQ 12, mostrou um índice geral bastante expressivo (16,8 \%) no grupo de operadores pesquisados.

19 Em estudo realizado por Peres (2003) no estado do Rio Grande do Sul, foi avaliada a satisfação dos operadores de uma empresa de telemarketing com o sistema de pausas para descanso no trabalho. Foi feito um levantamento com base em observação direta, entrevista e questionários respondidos por 170 operadores, onde se evidenciou insatisfação com o sistema de pausas utilizado, principalmente pelos operadores com maior tempo de serviço. Conforme informado por estes operadores, constatou-se baixa motivação e alta pressão psicológica. Do total de entrevistados, 15 operadores (12 \%) informaram terem sido acometidos por doença do trabalho, 4 mencionaram afonia, 7 mencionaram tendinite, 1 mencionou lombalgia e 1 mencionou otite.

Na cidade de Belo Horizonte (estado de Minas Gerais), pesquisa realizada em uma empresa de teleatendimento com 2.285 funcionários demonstrou que os serviços de atendimento no call center eram efetuados predominantemente por mulheres $(70 \%) \mathrm{e}$ apresentavam característica de expressiva rotatividade, ficando em torno de $2 \%$ ao mês, chegando à substituição de quase todo o efetivo (96\%) em dois anos. Utilizando métodos de análise ergonômica e análise dos relatórios de gestão, esse estudo concluiu que o trabalho de atendimento exigia dos(das) operadores(as) forte mobilização (corporal, cognitiva e afetiva), rapidez de raciocínio e flexibilidade, gerando uma hiperaceleração para compensar imprevistos e obedecer às exigências de tempo de atendimento médio por chamada (TMA). Constatou-se sinais de adoecimento e sofrimento psíquico nos trabalhadores : irritabilidade e auto-aceleração durante e após a jornada, acompanhadas de hiperemotividade e ansiedade latente (Villela \& Assunção, 2004).

21 Em pesquisa realizada por Segnini (2001), observa-se que no setor bancário brasileiro $88 \%$ do atendimento realizado via telemarketing é efetuado por mulheres. A autora constatou que nesse setor, as mulheres são consideradas mais "apropriadas" (e não "mais qualificadas") para a tarefa de telemarketing em decorrência de atributos pessoais construídos a partir de estereótipos como: voz mais suave, disponibilidade para ouvir, paciência, voz mais confiável, entre outros.

Offe (apud Segnini, 2001) aponta para a tensão observada entre a particularidade e a normatização presentes no conteúdo do trabalho em serviços, na época atual. Por particularidade compreende o autor a exigência de preservação da individualidade e da variabilidade presentes na prestação de um serviço perante as necessidades específicas de um cliente. Por outro lado, um conjunto de normas, regras e valores padronizam o trabalho em serviços. $O$ trabalho do setor de telemarketing representa um significativo exemplo disso, pois observa-se uma grande tensão entre esses dois pólos.

23 Assim, considerando que o setor do telemarketing é em sua maioria ocupado por operadoras do sexo feminino, podemos ver, a partir da fórmula de offe, a dupla face da desqualificação. No polo da particularidade exigem-se as qualidades estereotipadas, ditas femininas, como paciência, atenção, entre outras. No polo da normatização exige- 
se um trabalho repetitivo (conseqüência da racionalização) também atribuído ao feminino: capacidade de executar um trabalho simples, monótono, e efetuado de maneira conscienciosa.

\section{A relação saúde-trabalho : a perspectiva deste estudo}

Partindo das reflexões de Canguilhem $(2001,2006)$ e dos resultados das pesquisasintervenção da Ergonomia da Atividade, Schwartz (2000a, 2000b) afirma que o meio (milieu) de trabalho é sempre, de alguma forma, infiel. Essa infidelidade do meio deve ser gerida pelos trabalhadores não simplesmente como pura execução, mas por um uso de si. Isso quer dizer que o(s) trabalhador(es) - individual e coletivamente necessita $(\mathrm{m})$ mobilizar suas capacidades, recursos e escolhas para dar conta dessa infidelidade. Tais recursos são necessários porque as tarefas prescritas são sempre limitadas, contêm equívocos e são insuficientes para lidar com as variabilidades e o acaso. A maneira de cobrir esse déficit de normas será inevitavelmente uma maneira em alguma medida pessoal, uma tentativa de (re)centrar o meio como seu meio, (ou seja, em torno de sua própria história), ocorrendo assim um "debate de normas e valores" (Schwartz, 2007a). Ao operarem em um quadro de dramáticas de usos de si (por si e por outrem) os trabalhadores desenvolvem os saberes investidos.

Pode-se aqui resgatar as pesquisas realizadas por Cru $(1985,1987$ a, 1987b, 1995) e Cru \& Dejours (1987) sobre os saberes de prudência. O saber operário (consubstanciado nas regras e linguagem de ofício, tão importantes inclusive no plano psíquico) revela-se mais potente do que freqüentemente se crê. Cru formula a hipótese, radicalmente oposta aos discursos habituais sobre a prevenção (preventivistas), segundo a qual os trabalhadores de oficio conhecem em profundidade os perigos de seu trabalho e provavelmente se defendem espontaneamente (de um modo não perceptível e quase sempre não consciente). Um campo que a Clínica da Atividade, mobilizando Bakhtin, conceitua por gênero profissional, "uma segunda memória, desta vez objetiva e impesssoal" (Clot, 1999/2006, p. 49). No encaminhamento de Dejours (2008a), defesas não somente contra o medo (papel dos sistemas defensivos da profissão, neste caso, frequentemente ideologia defensiva), mas também contra os próprios riscos (neste caso, estratégias defensivas); e defendem-se concretamente, com a ajuda de procedimentos específicos eficazes, no decorrer do trabalho. Já nas pesquisas com pilotos de trem na França, seja de Schwartz (2000a), seja de Clot, revela-se que nem sempre se trata de defesa contra o medo, mas de defender-se através da intencional produção do medo, uma forma de antecipação. Nas palavras de um piloto: "eu crio medo para mim mesmo a fim de me manter no trabalho" (Clot, 2006, p. 179). 0 "medo se torna a motivação para a ação, (...) a ação 'demole' o medo. (...) $\mathrm{Na}$ ação, ele desvia seus medos e os subverte (...)" (p.180), uma estratégia diversa da pura defesa.

Para Schwartz (2007a), do mesmo modo que é impossivel manter a estabilidade do meio em que vivemos, e que é impossível eliminar as variabilidades desse meio (conforme também evidenciou a Ergonomia da Atividade), não se pode viver (daí é "invivivel") sob um regime de total imposição deste meio, isto é, das normas desse meio. Tal impossivel convoca um vivente que trabalha, apto a gerir as adversidades do meio. Frente às normas (antecedentes) impostas/propostas, os trabalhadores - para tornarem o meio vivível - criam estratégias, exercem sua capacidade normativa, em um movimento contínuo de (re)normatização. Não se limitando a procedimentos dirigidos à regulação 
do processo, o trabalhador busca modificar o meio de trabalho (inclusive as prescrições) mesmo que parcialmente e em escala infinitesimal, com renormatizações que são também orientadas pela busca de saúde e segurança.

Em vista disso, trabalhar nunca se limita a pura execução. Aqueles que trabalham estão sempre implicados em formas de uso de si, envolvendo a dialética do uso de si "por si" e "pelos outros" (Schwartz, 2000a). O uso de si pelos outros se deve ao fato de que ao trabalhar (ao viver) entra-se em um meio (de trabalho) já dado, onde já existem normas antecedentes, regras muito fortes de todos os tipos: científicas, técnicas, organizacionais, relações de subordinação, de poder, tudo isso ocorrendo conjuntamente. Ora, embora saibamos que não fazemos tudo o que desejamos, cada um vive tentando fazer valer, em cada situação, suas próprias normas de vida, suas próprias referências, através de uma síntese pessoal de valores. Isso nos remete à idéia de que ao mesmo tempo todo uso de si é uso de si por si mesmo - podemos vislumbrar tal uso principalmente frente às variabilidades e vazios de normas que os trabalhadores fazem para dar conta da tarefa prescrita.

\section{Abordagem metodológica}

Como ter acesso à inteligência e sabedoria da prática (Dejours, 2008a), aos conhecimentos incorporados e desenvolvidos se estes são, muitas vezes, desconhecidos no plano da consciência pelo próprio trabalhador e quase nunca são verbalizados em uma entrevista clássica? Conforme Athayde (2006), entendemos que alguns dos métodos predominantemente utilizados, envolvendo procedimentos como questionários e entrevistas, não facilitam a dialogia (remetendo aqui à concepção do Círculo Bakhtin). Entendemos que o método de confrontação e suas diferentes configurações técnicas, particularmente a de instruções ao sósia, favorecem a dialogia, a construção e desenvolvimento de saberes sobre o trabalho.

Essa técnica foi elaborada no contexto italiano da luta pela saúde no trabalho nos 1970, para ser utilizada junto aos operários da Fiat, com o intuito de melhor compreender $\leftrightarrow$ transformar a relação saúde-trabalho nas fábricas. Dada a interdição patronal de análise do trabalho na empresa, Oddone, Re e seus parceiros (Vasconcelos \& Lacomblez, 2005 ; de Vicenti, 1999 ; Clot, 1999) inventaram o exercício de instruções ao sósia. Ela implica em um jogo dramático no qual o pesquisador perguntava a um operário: "Suponha que eu seja teu sósia e que amanhã eu vá te substituir no seu trabalho. Que instruções você deve me transmitir a fim de que ninguém perceba a substituição ?" Delimitava-se então uma seqüência de trabalho determinada para facilitar a focalização da experimentação sobre os "detalhes do trabalho", interessandose, a princípio, mais sobre a questão do como do que sobre o por quê daquela atividade. Oddone, Re \& Brianti (1981) elaboraram essa técnica porque haviam observado que quando os operários eram simplesmente solicitados a falar sobre seu trabalho, eles tendiam a reproduzir um comportamento ideal, de acordo com o prescrito, tendo pouco a ver com o trabalho real, com sua atividade. A utilização dessa técnica permitiu que os trabalhadores percebessem a existência uma defasagem sempre presente entre $o$ modelo teórico gerado segundo a ótica da empresa e o modelo prático de produção que só podia ser ultrapassada pela intervenção deles mesmos. 


\section{Instruções ao sósia de uma operadora de telemarketing} como operador de telemarketing em uma grande empresa de telefonia celular. Nesse período, sob inspiração etnográfica, fez uso da "participação observante" e de anotações em um diário de campo. Esses registros foram posteriormente analisados, com o objetivo de contextualizar a situação de trabalho das operadoras.

Em um segundo momento, com vistas a um estudo exploratório inspirado na técnica de instruções ao sósia, convidamos para ampliar nossa comunidade de pesquisa a Eunice (nome fictício), uma jovem de 22 anos que trabalhava há 11 meses na mesma empresa, também como operadora de telemarketing. Mobilizou-se o que denominamos (Athayde, 2006) uma Conversa sobre o Trabalho entre o pesquisador [ ${ }^{1}$ ] e a operadora, quando solicitamos que ela desse as instruções ao sósia [ $\left.{ }^{2}\right]$ (no caso, ao pesquisador/ex-operador) de forma que, conforme a proposta metodológica do uso dessa técnica, ela pudesse se confrontar com sua própria atividade, explorando-se as controvérsias.

Quanto ao local da conversa, concordamos com Dejours (2008b) o quanto é importante desenvolver uma pesquisa em um local identificado com o trabalho, não necessariamente o próprio local de trabalho. Por esse motivo optamos por combinar com Eunice um encontro em um shopping localizado perto do seu local de trabalho às 14 horas, ou seja, duas horas antes do início de sua jornada, caracterizando um limite de 90 minutos para a conversa e o uso da técnica. Esse diálogo foi gravado e transcrito. Para a análise, partimos de alguns extratos da conversa que foram divididos em unidades temáticas, aqui denominadas cenas.

\section{Resultados e Discussão}

\section{O contexto das instruções ao sósia de Eunice : a empresa}

33 A empresa de telefonia celular em que Eunice trabalhava como operadora possui um serviço de teleatendimento que consiste em fornecer informações ao cliente através do uso constante da voz, sustentando-se nas novas tecnologias da informação e comunicação. $\mathrm{O}$ call center da empresa é organizado em postos de trabalho chamados de Posição de Atendimento (PA), totalizando 1.800 PAs, contando com aproximadamente 3.000 funcionários.

34 A jornada de trabalho de Eunice à época desse diálogo era das 16 às 22 horas. Conforme a legislação, sua jornada era de 6 horas, com uma pausa de 15 minutos para lanche e outra de 5 minutos para "ir ao banheiro". O chamado "serviço de atendimento" visa solucionar dúvidas, atender reclamações e orientar os seus clientes na utilização dos serviços relacionados ao aparelho celular, o que implica mobilizar capacidade de escuta e comunicação visando compensar as diferenças de toda ordem (culturais, lingüísticas, etc.) entre si e os diferentes clientes, dentre outras exigências a capacidade de reverter manifestações agressivas demonstradas pelos clientes insatisfeitos e/ou pouco informados.

Os(as) operadores(as) estão submetidos a uma série constrangedora de mecanismos de controle gerencial/patronal : de tempo, do conteúdo da informação prestada, da forma de falar e dos resultados obtidos. Esse controle sobre as atividades assume diversas 
formas : registro de cada atendimento pelos próprios operadores no sistema específico (através de um software); escutas telefônicas dos atendimentos em tempo real pelos trabalhadores da "monitoria", presentes fisicamente em uma sala especial ; controle da hierarquia que consolida em registros individuais os horários de chegada, saída, duração real das poucas pausas permitidas e absenteísmo. Semanalmente, são emitidas avaliações individuais que indicam a qualidade do atendimento, de acordo com os parâmetros da empresa: rapidez na identificação da demanda do cliente, dicção, empatia, tom de voz, atenção/interesse, tempo médio de atendimento (TMA), entre outros. É importante ressaltar que as escutas telefônicas são realizadas, em média, em três chamadas telefônicas por semana. $O$ operador, portanto, sabe que ele pode estar sendo "escutado", mas nunca sabe quando isso acontece.

A avaliação de desempenho individual de todos operadores é divulgada publicamente, em painéis nos corredores, por meio de tabela de cores com colunas horizontais. A meta individual para cada operador(a) é atingir 90 pontos nesta avaliação, em uma escala de 0 a 100. As operadoras que têm nota acima de 90 aparecem com uma coluna horizontal de cor verde ao lado de seu nome; as que ficam entre 80 e 90 aparecem com uma coluna em amarelo, já as operadoras que ficam abaixo de 80 aparecem em vermelho. Esta nota varia de setor para setor.

Cena 1- A chegada no lugar de trabalho : recuperação e recentramento do meio

\begin{tabular}{|c|c|}
\hline \multicolumn{2}{|r|}{ Cena 1: A chegada no lugar de trabalho: recuperação e recentramento do meio } \\
\hline 1 & $\begin{array}{l}P[3] \text {-Vamos supor que eu sou seu sósia [4] e amanhã eu vou te substituir no seu traba- } \\
\text { lho, e você teria que dar instruçôes para mim, que não conheço, o que eu deveria fazer, } \\
\text { sendo que as pessoas não poderiam perceber que não seria você. }\end{array}$ \\
\hline 2 & $\begin{array}{l}0 \text { - Como se você fosse minha irmã gêmea e me substituísse sem que ninguém soubes- } \\
\text { se... }\end{array}$ \\
\hline 3 & $\begin{array}{l}\mathrm{P} \text { - Exato! Que instruçōes você me daria para realizar esse trabalho sem que ninguém } \\
\text { percebesse. Primeiramente, chegando na empresa, o que eu deveria fazer? }\end{array}$ \\
\hline 4 & $\begin{array}{l}0 \text { - Chegando na empresa você deveria chegar bem cedo, uns } 30,40 \text { minutos antes do } \\
\text { seu horário... }\end{array}$ \\
\hline 5 & P-Por quê? \\
\hline
\end{tabular}




\begin{tabular}{|c|c|}
\hline 6 & $\begin{array}{l}\text { 0-Porque eu costumo chegar cedo, arrumar minha PA, abrir o sistema [5], ler, tem } \\
\text { sempre umas notícias novas pra você ficar se inteirando, então eu gosto de ler o sistema, } \\
\text { abrir tudo, ler, ir no banheiro, tomar minha água, sentar lá na sala, ver a televisão... } \\
\text { relaxar um pouco. Quando eu chego em cima da hora, } 10 \text { minutos pra me logar [6], eu não } \\
\text { me logo a mesma pessoa, me logo cansada, sei lá, parece que foi tudo muito corrido. } \\
\text { As vezes a gente fica assim na PA, conversando mesmo, mais sobre meu trabalho, } \\
\text { ninguém consegue conversar comigo que eu só sei falar do meu trabalho. Eu adoro } \\
\text { mesmo de verdade o que eu faço, mesmo. Tudo bem que não é o que eu quero para mim } \\
\text { futuramente, mas é muito bom. E o que mais? Você teria que ter... dúvidas, esclarecer } \\
\text { sempre. Meu supervisor costuma brigar comigo porque tudo eu pergunto, ele diz que } \\
\text { são coisas fáceis, óbvias, tudo eu pergunto. Mas eu pergunto porque eu quero passar a } \\
\text { informação correta. Eu quero me destacar, é uma área quevocê tem muita oportunidade, } \\
\text { você tem como crescer. Você entra ali, mas não fica como operador pra sempre se você se } \\
\text { empenhar e for um bom profissional. }\end{array}$ \\
\hline 7 & P. Entāo eu tenho que perguntar muito, porque essa é uma caracteristica sua. \\
\hline 8 & $\begin{array}{l}0 \text {-E, esclareça sempre suas dúvidas, por mais simples que for a pergunta do cliente e } \\
\text { você não está convicto do que você vai falar, pergunte. Primeiramente, nunca ligue para o } \\
\text { supervisor direto, procure no sistema, pergunte ao operador do seu lado, que é a pessoa } \\
\text { mais capacitada a te orientar, em último caso você pergunta à supervisão. }\end{array}$ \\
\hline 9 & $\begin{array}{l}\text { P-Então, eu cheguei } 40 \text { minutos antes, procuro uma PA... Acontece muito de não ter uma } \\
\text { PA vaga? }\end{array}$ \\
\hline 10 & 0 - Não, tem... \\
\hline 11 & P-Se eu chegar muito perto do horário... \\
\hline 12 & $\begin{array}{l}0 \text { - Não é nem para arrumar a PA, é pra arrumar seu canto, você ler o sistema, pra você ir } \\
\text { se relaxando. }\end{array}$ \\
\hline
\end{tabular}

[3] P - pesquisador /sósia; O - operadora/instrutora

[4] Apesar dessa técnica ter o nome de instruções ao sósia, não é necessário utilizar essa palavra ao iniciar o diálogo com os trabalhadores. Isso fica claro na fala da operadora, no segundo enunciado, quando ela afirma que a pessoa a substituí-la é como se fosse sua "irmã gêmea".

[5] O conjunto de programas (softwares) usados como ferramentas para o atendimento.

[6] "logar": expressão usada pelas operadoras para dizer que elas se conectaram ao computador e ao telefone, entrando no sistema da empresa com a respectiva senha individual.

Nota-se que ao chegar à empresa a operadora configura uma atividade de recuperação/ preparação para o trabalho (ela própria um trabalho intenso). Efetua uma série de ações que, por um lado, remete à impossibilidade de fazê-lo durante o próprio exercício da atividade (dados os constrangimentos temporais do TMA); por outro lado, em seqüência, tais ações têm ressonância com o meio doméstico : "ler, ir no banheiro, tomar minha água, sentar lá na sala, ver a televisão... relaxar um pouco". Essa instrução nos remete ao que dizia Canguilhem (2001, p. 120) : "os operários não tomam como autenticamente normais senão as condições de trabalho que eles mesmos instituem em referência a valores próprios". Ao relatar a "chegada" à empresa, a operadora parece estar fazendo ressonância simbólica com sua própria casa, estabelecendo uma certa transição entre o meio doméstico (de onde vem) e o meio de trabalho (onde pretende de fato chegar). Parece-nos um esforço para dar ao meio de trabalho uma significação concreta para um indivíduo tomado em sua totalidade bio-psicológico-social. Percebemos esse esforço de significação quando no enunciado 12 a própria operadora se corrige, dizendo que ela chega mais cedo não exatamente para arrumar (fisicamente) seu posto de trabalho (PA) e sim para "arrumar seu canto e ir se relaxando", transitando para o trabalhar em tempo real e tentando ter um mínimo de controle pessoal e profissional sobre o processo de trabalho (exigências de saúde), com vistas à produtividade e qualidade.

38 O uso recorrente de pronomes possessivos como "minha água", "minha PA", "meu trabalho", indicam uma postura ativa da operadora de realizar o que Schwartz (2007b), 
com Canguilhem, chama de "recentramento do meio" em torno de suas próprias normas de vida, um esforço que se faz para que esse meio deixe de ser anônimo e tome uma forma mais pessoal.

Podemos também considerar como atividade de preparação para as atividades a serem desenvolvidas, o fato de a operadora dizer que nesse período anterior ao início da jornada oficial remunerada, ela fala com os colegas exclusivamente de assuntos relacionados ao trabalho. Percebemos que essa conversa com os colegas seria mais um elemento transicional para que ela possa "mergulhar" no trabalho com mais saúde, segurança, produtividade e qualidade. Estamos falando, portanto, de saúde enquanto capacidade que temos de apreender e desconstruir algo que já recebemos pronto, desenvolvendo as condições para a criação de novas regras de acordo com nossos interesses, valores, nossas próprias normas. Entendemos que os 30/40 minutos que antecedem o horário do início da jornada formal correspondem a um tempo necessário para se organizar e fortalecer no plano da saúde, ou seja, uma norma de proteção à saúde criada no curso da atividade, considerando as exigências de produtividade e qualidade e os constrangimentos temporais do TMA.

Já no enunciado 6 observamos que a operadora faz o movimento de ir além da proposta inicial de dar instruções ao sósia e começa a fazer uma reflexão sobre o seu próprio trabalho. Diz enfaticamente que gosta muito do que faz... apesar de não querer aquele trabalho para seu futuro. Eunice também afirma que se for uma boa profissional - como ela se empenha em ser - pode crescer na empresa e deixar de fazer o que gosta, ou seja, deixar de ser operadora, mas trabalhando neste tipo de serviço. Entendemos que essa fala, a princípio contraditória, reflete uma tentativa - muito difícil e frágil - de encontrar este ponto de equilíbrio entre suas próprias normas e as rígidas normas da organização (um equilibrismo ?). Ao colocar ênfase no prazer que encontra naquilo que faz ("eu adoro!"), Eunice procura se colocar de uma forma mais plástica em relação ao seu trabalho, ressaltando o que tem valor para ela, o que representa, em princípio, uma tensão em direção à saúde. 
Cena 2 - Sentar ou não perto de conhecidos : formação de "entidades coletivas relativamente pertinentes" (ECRP)

\begin{tabular}{|c|c|}
\hline \multicolumn{2}{|r|}{$\begin{array}{l}\text { Cena 2: Sentar ou nāo perto de conhecidos: formaçāo de "entidades coletivas relativamente } \\
\text { pertinentes" (ECRP) }\end{array}$} \\
\hline 13 & P- (ao chegar no trabalho). Eu procuraria sentar perto de pessoas conhecidas, ou... \\
\hline 14 & $\begin{array}{l}\text { 0- Pessoas conhecidas, sempre. Nós procuramos até guardar lugar pros outros, próxi- } \\
\text { mos, ao lado, pra poder... porque são pessoas que podem te ajudar, até mesmo quando } \\
\text { não tem ligação, conversar, distrair, porque às vezes são } 6 \text { horas, mas há pouquinho } \\
\text { tempo. Mas você sabe que não é nem um pouquinho quando tá bombando [7]. }\end{array}$ \\
\hline 15 & P-Acontece alguma vez de eu chegar lá e não encontrar lugar? \\
\hline 16 & $\begin{array}{l}\text { 0-Acontece, agora mesmo tá acontecendo. A gente costuma se logar na PA de outras } \\
\text { pessoas. Porque agora eu tô em "pós [8]", mas o pós foi dividido em } 2 \text { setores, pós-ouro e } \\
\text { pós-diamante. Eu tô no setor de pós-diamante, é um setor menor, mas e agora eles colo- } \\
\text { caram outro setor, "dealer [9]", que é para ativaçầ, lá no setor do pós-diamante que é um } \\
\text { setor pequeno e năo tá sobrando lugar pra gente se logar e a gente se loga no pós-ouro, } \\
\text { ai você vai sempre pra ilha [10] dos outros. }\end{array}$ \\
\hline 17 & P-E sempre eu conseguiria sentar perto dos conhecidos? \\
\hline 18 & $\begin{array}{l}0 \text { - Na maioria das vezes você senta perto de pessoas conhecidas, mesmo quando não } \\
\text { tem lugar na sua equipe você senta perto de pessoas conhecidas. Por ter esse lance } \\
\text { de muita migração [11], você conhece muita gente, você conhece pessoas de todos os } \\
\text { setores. Em todo lugar quevocê sentarvocê senta perto de um conhecido e se não for } \\
\text { conhecido você passa a conhecer. }\end{array}$ \\
\hline
\end{tabular}

[7] A expressão "bombando" é um termo usado pelas operadoras para se referirem a uma situação típica e crítica desse tipo de trabalho que é o momento de pico das ligações. Nesse momento de pico a fila de clientes em espera está grande e devido a isso, não há intervalo entre uma ligação e outra. Pode durar de 30 minutos até 6 horas (jornada inteira de trabalho), dependendo da época do ano. [8] A operadora quer dizer que trabalha no setor de celulares pós-pagos, ou seja, no setor cujos clientes possuem celular de conta. Esses clientes fazem as ligações telefônicas e mensalmente eles pagam o valor equivalente ao tempo dessas ligações já efetuadas. Pós-Ouro e Pós-Diamante são subdivisões do setor pós-pago. São setores destinados a clientes VIPs, que têm um plano mensal que custa acima de um determinado valor. O Pós-Diamante tem menor número de clientes que o PósOuro justamente devido ao elevado valor do plano.

[9] "Dealer" é o nome que normalmente se dá a um setor de "venda especializada". Nesse caso específico o "dealer" é destinado à negociação e ativação de contas de potenciais clientes "ouro" e "diamante".

[10] "Ilha" é o nome que se dá à subdivisão de um setor. Um setor é composto por determinado número de ilhas. Pós-diamante é uma ilha do setor Pós-pago.

[11] Termo usado para designar as freqüentes mudanças de setor solicitadas pela empresa ao operador. Essas mudanças referem-se aos diferentes setores ou ilhas de atendimento como: clientes pré-pago, pós-pago, pessoa física, pessoa jurídica, etc

Percebemos nos enunciados 13 a 18 uma outra dimensão do trabalho de teleatendimento : sua dimensão coletiva. Embora a avaliação sobre os resultados pese individualmente para cada trabalhador, notamos que para o trabalho ser efetuado, existe a presença indispensável da cooperação entre colegas. O operador, mesmo isolado, jamais se encontra inteiramente só diante de seu trabalho. Os coletivos de trabalho apóiam-se em regras de ofício, fundamentalmente não escritas, que transcendem a esfera da hierarquia. São parte da dinâmica de auto-regulação no interior dos coletivos e apóiam-se na experiência dos trabalhadores ("inteligência e sabedoria da prática", conforme Dejours, 2008a), exercendo dessa forma papel vital na defesa coletivamente engendrada contra os riscos e contra o medo (ou pelo medo). Além disso, é graças à eficiência do coletivo que os erros humanos podem ser 
minimizados e, nesse sentido, a cooperação (Dejours, 1993, 2004) exerce um papel estratégico, tanto no que tange à busca de produtividade e qualidade quanto de saúde e segurança.

Podemos observar que estes coletivos têm contornos variáveis, se fazem e desfazem/ refazem. Schwartz (2007a) denomina de Entidades Coletivas Relativamente Pertinentes (ECRP) esses coletivos cuja plasticidade e geometria variável distinguem-se dos grupos e equipes visíveis nos organogramas das empresas. No enunciado 16 Eunice fala, por exemplo, de uma situação passageira, contudo bastante comum : o fato de ela ter que se logar em um setor diferente do seu devido a uma transição organizacional. Ela trabalha no setor "pós-diamante" mas momentaneamente ela está se logando no "pós-ouro". Eunice continua atendendo clientes "diamante", no entanto, trabalha fisicamente ao lado de colegas que atendem clientes "ouro", dado que não tem espaço sobrando no seu setor.

No enunciado 18 Eunice fala que apesar de não encontrar lugar perto de sua equipe, ela senta perto de pessoas conhecidas, algo que não é difícil acontecer porque ela diz conhecer muita gente, de todos os setores. Ao fazer seu comentário a respeito, ela explicita uma característica do trabalho nessa empresa que é a "migração": termo usado para designar as frequentes mudanças de setor impostas pela empresa onde ela trabalha. É curioso perceber que, a princípio, isso não representa um problema para Eunice, pois ela trata com muita naturalidade essas mudanças, como vemos ainda no enunciado 18 : "em todo lugar que você sentar você senta perto de um conhecido e se não for conhecido você passa a conhecer."

Na situação acima podemos distinguir claramente as ECRP e o que é apresentado no organograma, assim como nos postos pré-definidos pela empresa. Uma ECRP não se limita a uma equipe pré-definida, ela é situada, suas fronteiras são aquelas definidas num momento dado, frente a um desafio concreto. Ou seja, é impossível definir uma ECRP sem se ater a uma situação específica. A história da empresa é feita de uma combinação indefinida de fronteiras que se constroem e se reconstroem sem cessar.

Notamos que nos enunciados 14 e 16, Eunice fornece instruções usando os termos "nós" e "a gente", indicando que o comportamento de guardar lugar para os outros não lhe é exclusivo , é pertinente a um coletivo. Apesar da técnica de instruções ao sósia iniciar por uma pergunta muito pessoal, que procura descobrir que instruções um substituto (sósia) deve receber para que as outras pessoas não percebam a mudança, entendemos, nessa situação, que a técnica pode também apontar comportamentos, regras que se referem ao gênero profissional (Clot, 2006) do coletivo de trabalhadores. Mobilizando a obra de Bakhtin, para Clot (op.cit.) um gênero profissional retém a memória impessoal de um meio. Comporta regras que organizam a relação dos trabalhadores entre si, bem como o que se considera justo ou injusto. $O$ gênero profissional conserva e transmite a história social, sendo ao mesmo tempo o instrumento técnico e psicológico de um dado meio de trabalho e de vida.

No entender de Clot o gênero profissional conserva uma função psicológica para cada trabalhador, seja porque ele serve para agir, para se defender ou para tirar o melhor partido da situação de trabalho. Como contraponto ao deslocamento heterodeterminado da "migração" imposta pela empresa, Eunice e suas colegas de trabalho transformam essa situação em uma forma de expandirem seus contatos e de estarem abertas a conhecerem outras pessoas que vão poder fortalecer os coletivos de rede (Athayde, 1996) e as ECRP. 
Cena 4 - Atividade multifacetada

\begin{tabular}{|c|c|}
\hline \multicolumn{2}{|c|}{ Cena 4: Atividade multifacetada } \\
\hline 67 & P-Esse sistema que você fala, ele tem quantos programas? E apenas um programa? \\
\hline 68 & $\begin{array}{l}\text { 0-Não, nós trabalhamos na verdade com, deixa eu pensar, Siebel [12], PMS, Intranet } \\
\text { [13]...Quatro programas, trabalhamos com quatro programas. Somente dois desses } \\
\text { programas são os mais utilizados, até mesmo porque dois deles são mais específicos } \\
\text { para cliente cartão. Então, como eu hoje eu trabalho com cliente conta pós, eu não utilizo } \\
\text { esses programas. }\end{array}$ \\
\hline 69 & P-Quais săo esses programas, o que eles fazem? \\
\hline 70 & $\begin{array}{l}\text { 0-A intranet você verifica informaçōes, tudo que o cliente te perguntar vocêverifica na } \\
\text { intranet, perguntas tanto sobre reclamaçōes, dúvidas, produtos, serviços, tudo você } \\
\text { localiza na Intranet. A maior parte desses serviços você processa no Siebel. Na intranet } \\
\text { você verifica, no Siebel você ativa, registra reclamação na linha do cliente. A intranet } \\
\text { serve pra você pesquisar como se fosse um livro. }\end{array}$ \\
\hline 71 & $\begin{array}{l}\text { P-Isso é simples? Como eu lido com isso? Eu recebo a ligação, tenho que pesquisar no } \\
\text { programa e registrar. Isso é simples de fazer? }\end{array}$ \\
\hline 72 & $\begin{array}{l}\text { 0-Esimples. Tudo é questão de adaptaçâo. Você no início (risos) até fica um pouco as- } \\
\text { sustado, até mesmo porque a gente fica próximo às pessoas... eu achei que eu não ia me } \\
\text { adaptar de forma alguma porque muitas das vezes você tem que ouvir o cliente, digitar e } \\
\text { verificar tudo ao mesmo tempo. Então processar muitas informaçôes ao mesmo tempo, } \\
\text { até mesmo por causa do TMA. Se você não faz tudo ao mesmo tempo, o seu TMA vai lá em } \\
\text { cima e você pode ser penalizado por isso. Mas tudo é questão de adaptação. Com o tempo } \\
\text { você já vai falando com o cliente, o cliente pergunta e você já vai falando, já até decora } \\
\text { mesmo as informações. Mas mesmo decorando, é importante você verificar. }\end{array}$ \\
\hline
\end{tabular}

[12] Siebel é o nome do programa no qual a operadora registra os atendimentos e verifica os dados cadastrais do cliente.

[13] Na Intranet estão o "script", as normas da empresa e os procedimentos a serem adotados pelo operador nas diferentes situações de atendimento

Uma das características geradoras de desgaste e mal-estar no trabalho de telemarketing é a forte mobilização cognitiva exigida. A intensificação do trabalho nas centrais de atendimento provoca a execução de dupla ou tripla atividade (falar, escrever e navegar) em contexto de forte pressão temporal e de desempenho vigiado. A concentração exigida pela atividade cognitiva tem como conseqüência a rigidez postural e os riscos de doenças ocupacionais como a LER/DORT.

Zarifian (2002) afirma que uma das competências centrais desenvolvidas pelos operadores nesse tipo de trabalho é a memorização e constante atualização de seus conhecimentos, em particular sobre novos produtos e serviços. O enunciado 72 explicita bem esse tipo de competência que é adquirida com o tempo: "Com o tempo você já vai falando com o cliente, o cliente pergunta e você já vai falando, já até decora mesmo as informações. Mas mesmo decorando, é importante você verificar". Ouni (1998, apud Santos, 2004) afirma que ao lidarem repetidamente com uma situação complexa, como é o caso da tripla atividade, os operadores passam de um tratamento controlado da situação a um tratamento mais automático, o que torna o processo de gestão da atividade mais rápido e eficiente. Isso se deve ao desenvolvimento de algumas competências por parte dos operadores. A aquisição e o desenvolvimento dessas competências não são nada simples. Expressam um custo cognitivo que é imposto sob a forma de aprendizagem necessária, resolução de problemas e tomada de decisão.

Para Zarifian as ferramentas de gestão utilizadas no call center, o peso das prescrições, acabam constituindo um sistema no qual a noção de competência (tomada de iniciativa 
e sentido de responsabilidade, apelo à inteligência e à cooperação) não tem oficialmente lugar. Tal situação faz com que os próprios operadores não reconheçam claramente o desenvolvimento dessas competências. Podemos perceber isto quando no enunciado 72 a operadora diz que realizar várias atividades ao mesmo tempo sob pressão temporal é "simples" e que tudo é uma "questão de adaptação".

Cena 5 - Adversidades relativas ao TMA

\begin{tabular}{|c|c|}
\hline \multicolumn{2}{|c|}{ Cena 5: Adversidades relativas ao TMA } \\
\hline 27 & $\begin{array}{l}\text { P-Eu tenho que atender essas ligações em um tempo mínimo? Posso ficar muito tempo } \\
\text { com o cliente? }\end{array}$ \\
\hline 28 & $\begin{array}{l}\text { 0-Agora cada vez mais esse tempo tá reduzindo. A empresa tá muito exigente, você tem } \\
\text { que ser rápido, direto, objetivo, que o cliente te entenda na primeira frase. Perguntou, } \\
\text { você respondeu e ele tem que te entender, mesmo DDD } 88 \text { vai ter que te entender, porque } \\
\text { TMA tá sendo muito exigido. }\end{array}$ \\
\hline 29 & P-TMA é o que? \\
\hline 30 & $\begin{array}{l}\text { 0-E seu tempo médio de atendimento. Girando em torno de três minutos em média, } \\
\text { ultrapassando três o seu TMA tá alto. Mas hoje em dia está dividido por equipe, por } \\
\text { setor, cada setor tem seu TMA especifico. Transferência você tem que evitar ao máximo. } \\
\text { Agora que estamos trabalhando com cliente pós-pago, ele solicitando o cancelamento, } \\
\text { nós não fazemos, encaminhamos para outro setor. Então você tem que entender porque } \\
\text { o cliente quer cancelar a linha dele e convencê-lo que a empresa que você trabalha é a } \\
\text { melhor possivel que se ele cancelar ele vai se arrepender, pra não transferir o cliente de } \\
\text { forma alguma. }\end{array}$ \\
\hline
\end{tabular}

Nessas instruções notamos que o Tempo Médio de Atendimento (TMA) é uma prescrição central na atividades dos operadores. Essa prescrição apresenta a peculiaridade de exigir da operadora que ela responda às chamadas em um tempo dado, qualquer que seja a complexidade do problema colocado pelo cliente. Eunice comenta nos enunciados 28 e 30 duas situações em que ela tem que fazer a gestão desse tempo.

51 A primeira situação se dá quando ela atende um cliente em que o DDD é 88, ou seja, o cliente é de Fortaleza - Ceará. Ela se refere a clientes que têm dificuldade em entender as informações passadas por ela devido às diferenças lingüísticas regionais (sotaques). A empresa atende clientes de todo o Brasil, mas sua sede é no Rio de Janeiro e seus operadores falam como cariocas. Isso gera problemas de entendimento mútuo entre os operadores e os clientes. Nesse caso, Eunice chama a atenção para o fato de que ela tem que se desdobrar para atender às chamadas no mesmo tempo mínimo, independente das dificuldades que surjam devido a essa diversidade lingüística. Atender um cliente do Rio de Janeiro acaba se tornando mais rápido do que atender um cliente do Ceará. As dificuldades de entendimento fazem com que os operadores tenham que repetir algumas vezes as informações passadas ao cliente de forma que fiquem inteligíveis. Da mesma forma, a operadora freqüentemente pede para que o cliente repita a solicitação para conseguir "decifrar" as gírias e os sotaques.

52 A segunda situação relatada por Eunice se dá no atendimento de um caso específico que é crítico para a empresa : o cliente quer cancelar sua linha. Eunice não pode fazer o cancelamento, pois quem faz esse tipo de serviço é outro setor. Apesar disso a empresa diz para Eunice que ela deve evitar ao máximo fazer a transferência para o setor de cancelamento. A operadora deve então tentar convencer o cliente a não cancelar sua linha, dentro do mesmo TMA de 3 minutos. 
Nessas duas situações percebemos que a operadora encontra-se diante de prescrições muito contraditórias. Há um conflito latente entre as normas de produtividade às quais ela está submetida (TMA) e aquilo que parece central para a empresa : a "fidelização" do cliente. Os mecanismos de disciplina e controle da empresa acabam enfatizando mais um aspecto quantitativo das atividades de teleatendimento do que a qualidade da relação de serviço que a operadora estabelece com o cliente.

Cliente não entende

\begin{tabular}{|c|c|}
\hline \multicolumn{2}{|c|}{ Cliente nāo entende } \\
\hline 53 & $\begin{array}{l}\text { P-Acontece algumas vezes de o cliente não entender alguma coisa, mesmo você falando } \\
\text { claramente? }\end{array}$ \\
\hline 54 & 0 -Muitasvezes. \\
\hline 55 & $P-0$ que eu devo fazer nesse momento? \\
\hline 56 & $\begin{array}{l}\text { 0- Mudar a forma como você está utilizando para explicar. Tem que usar várias... eu } \\
\text { costumo usar exemplos que nós temos no nosso dia-a dia pra ele tentar entender. Essa } \\
\text { semana mesmo eu peguei um cliente assim. Ele não entendia porque ele estava sendo } \\
\text { cobrado proporcionalmente na fatura dele (trecho de fala da operadora que não foi possi- } \\
\text { vel transcrever) igual eu peguei um cliente ontem que ele acessou a internet do aparelho } \\
\text { dele pra comprar sons e imagens. Não conseguiu comprar e na fatura dele veio a cobrança } \\
\text { do acesso à internet. Ele não concordou com a cobrança do acesso à internet. Então eu } \\
\text { tive que convencê-lo de que ele não foi cobrado do serviço que ele solicitou, mas o acesso } \\
\text { à internet foi acessado com sucesso, ele teve o serviço disponivel, então a cobrança } \\
\text { estava correta. Não gostou muito nâo, mas ele aceitou. }\end{array}$ \\
\hline 57 & P-Aceitou? \\
\hline 58 & 0 - Tem que aceitar. E o procedimento. \\
\hline
\end{tabular}

Como dar conta das exigências de produtividade e qualidade senão transgredindo a prescrição ? Nesse trecho percebemos que o script fornecido pela empresa muitas vezes não é suficiente para que a operadora responda às dúvidas dos clientes, exigindo uma mobilização constante e uma inventividade para fornecer a informação correta sem extrapolar seu TMA. Entretanto, um dos critérios de bom atendimento definido pela empresa é a "adequação ao script".

o exercício profissional remete o indivíduo a algo como suas escolhas, ou seus dramas pessoais. No interior das coerções materiais e sociais - trabalhando-as -, abre-se o espaço para uma gestão diferenciada de si mesmo. Repetir o script ou buscar outra forma de fornecer a informação? Os debates dos trabalhadores consigo mesmos são tecidos com os atos cotidianos do trabalho. Para que a produção se realize, para que objetos e serviços sejam vendáveis (se transformem em mercadorias), os prescritores do trabalho não encontram autômatos ou mortos-vivos. Trabalhar é fazer usos de si, ou seja é lugar de uma tensão problemática, de um espaço de possíveis sempre por negociar (Schwartz, 2000a) . É o trabalhador em seu ser que é convocado: "costumo usar exemplos que nós temos no nosso dia-a dia...". A tarefa cotidiana requer recursos e capacidades infinitamente mais vastos que os que são explicitados.

Eunice, referindo-se ao cliente, fala no enunciado 58: "Tem que aceitar. É o procedimento". Quando assume essa postura aparentemente rígida, Eunice parece dizer 
não estar disposta a fazer senão o uso que a empresa faz dela. Entretanto, a operadora esforça-se em convencer o cliente e utiliza-se de exemplos que ela encontra no seu cotidiano. Ao utilizar-se de sua experiência para explicar ao cliente, ela também faz um uso de si mesma. Como afirma Schwartz, "fundamentalmente, todo ato de trabalho humano se desenvolve no híbrido" (2000a, p. 55).

Criação/exclusão de expressões verbais

\begin{tabular}{|c|l|}
\hline \multicolumn{2}{|c|}{ Criação / exclusão de expressões verbais } \\
\hline 101 & O-Algo mais? Não se deve falar "algo mais" para o cliente... \\
\hline 102 & P-Ah, não ? Não devo falar "algo mais"? \\
\hline 103 & $\begin{array}{l}\text { 0-Algo mais, nunca pergunte! Eu tenho vício, jă é automático, sempre falo. Mas a } \\
\text { orientação a novas operadoras é não pergunte "algo mais" porque embora ele não tenha } \\
\text { o que perguntar, ele vai criar. Eu costumo às vezes perguntar, o senhor compreendeu a } \\
\text { informação? }\end{array}$ \\
\hline
\end{tabular}

Que palavras usar para que o atendimento não se prolongue ? Uma das exigências de produtividade cobrada pelas empresas é o TMA. Outra exigência : o operador nunca deve encerrar a ligação, pois deve esperar o cliente fazê-lo. Eunice relata que evita a pergunta "algo mais ?", pois mesmo o cliente não tendo mais nenhuma dúvida essa expressão pode induzi-lo a "criar" ou lembrar-se de outras dúvidas. Para que isso não aconteça, ela utiliza outra expressão que não dê margem para que o atendimento dure mais tempo do que o exigido : "o senhor compreendeu a informação ?".

Notamos nesse caso que expressar-se por meio da linguagem é ao mesmo tempo agir. É, sobretudo, intervir de maneira simbólica nas relações entre as pessoas. Faïta (2005) diz que combinamos as palavras entre elas, formando conjuntos que são os enunciados. No interior desses enunciados, dessas combinações, as palavras vão adquirir sentidos diferentes das significações que encontramos no dicionário. Se pegarmos isoladamente a seqüência de palavras "o senhor compreendeu a informação ?", estamos no universo da significação: uma pessoa deseja saber se a outra com a qual está dialogando compreendeu a informação fornecida. Entretanto, se entendermos que o sentido se constrói no contexto de uma situação específica, no enunciado acima subentende-se a sugestão do ato de encerramento de um atendimento telefônico, de um serviço. Aí teríamos efetivamente o sentido manifestado na situação. Esses códigos que se constroem na atividades pelos operadores poderiam ser utilizados em benefício da própria empresa e do trabalhador, servindo para repensar a separação muito rígida entre o trabalho de concepção e o trabalho de execução presente nos serviços de teleatendimento / telemarketing. 


\begin{tabular}{|c|l|}
\hline \multicolumn{2}{|c|}{ Cena 7: 0 peso do instante } \\
\hline 35 & $\begin{array}{l}\text { P-A ligação acontece uma atrás da outra direto ou tem alguns períodos de pausa nas } \\
\text { ligaçôes. }\end{array}$ \\
\hline 36 & $\begin{array}{l}\text { 0-Tá mais tranqüilo agora, de } 5 \text { em } 5 \text { minutos cai uma ligação, intervalo de três, dois } \\
\text { minutos. A gente tá conseguindo respirar um pouco agora. Tudo depende do período, são } \\
\text { épocas, às vezes dá alguma coisa errada no sistema, tem sempre exceçôes. Na maioria } \\
\text { das vezes o atendimento é tranqüilo, mas tem aquelas exceçōes que dá aquela filinha } \\
\text { básica. }\end{array}$ \\
\hline 37 & $\begin{array}{l}\text { P-Acontece às vezes de eu ficar cansado, esgotado? } \\
\text { de falar. Étezmplicado, você trabalha falando. Você não tem outra forma de se expressar } \\
\text { com o cliente uma vez que ele não vê você e você com preguiça de falar. Acontece real- } \\
\text { mente, a gente fica cansado, a garganta da gente é um órgão muito sensivele tem que dar } \\
\text { a volta por cima, forçar e vamos lá. }\end{array}$ \\
\hline
\end{tabular}

A tecnologia empregada atua na intensificação, no aumento da cadência do trabalho. Há um distribuidor automático programado para que as ligações cheguem às PAs, ininterruptamente. Quando há fila, encerrando um contato, automaticamente se disponibiliza uma nova chamada para o operador. Um dos problemas do trabalho em call center é que os operadores sofrem um peso permanente do instante, das contínuas chamadas, que bloqueia a reflexão e dificulta o distanciamento do operador daquilo que ele faz.

No caso de Eunice, por exemplo, em um dia de atendimento considerado tranqüilo os operadores atendem uma ligação de 5 em 5 minutos, totalizando ao final da jornada de trabalho quase 70 chamadas. Nesses dias em que o fluxo de chamadas não é tão intenso, Eunice diz "conseguir respirar" nos intervalos de 2 a 3 minutos entre essas chamadas. Nos dias de pico, quando há fila, esse número chega perto de 150 chamadas, sem intervalo entre elas.

Dejours (1994) entende que diante de uma pressão patogênica os trabalhadores constroem defesas, minimizando a percepção que eles têm dessas pressões, fonte de sofrimento. Podemos observar no enunciado 38 que Eunice usa as expressões "preguiça de falar" e "dar a volta por cima" como uma forma de eufemizar a realidade. A operadora interpreta seu cansaço, originado por um resfriado que debilita seu instrumento de trabalho, a "garganta", como sendo uma atitude preguiçosa. De fato, é mais fácil dar a volta por cima na preguiça do que em um corpo adoecido. $\mathrm{Na}$ falta de poder vencer a rigidez da organização do trabalho, Eunice faz uso de um procedimento defensivo que não muda a realidade de imediato, mas permite que ela continue trabalhando.

\section{Considerações Finais}

61 Ao utilizarmos a técnica de instruções ao sósia, percebemos que a elaboração e a formalização da experiência acontecem à medida que a protagonista da atividade, em diálogo com o híbrido de pesquisador-leigo/ex-operador, se confronta com os numerosos problemas que a tocam pessoalmente em suas atividades. Segundo Brito e 
Athayde (2003), a relação dialógica quando se estabelece com os trabalhadores sinaliza conflitos e dificuldades que estão presentes em suas próprias atividades de produção, mas que só podem ser melhor compreendidos com uma abordagem situada e que privilegie suas experiências cotidianas.

O método da confrontação, especialmente a técnica de instruções ao sósia ainda é pouco utilizada no Brasil. Portanto, na pesquisa que apresentamos procurou-se fazer uma experimentação-piloto clínica, com apenas uma operadora. A maioria das situações adversas relatadas pela operadora são relativas ao estabelecimento de um tempo médio de atendimento (TMA) que deve ser cumprido independente do tipo de cliente e de situação enfrentada. Tais adversidades são identificadas ao longo das diversas "cenas" aqui descritas. A combinação das dificuldades relativas ao TMA faz com que o trabalho em call center seja marcado pelo peso permanente do instante, das contínuas chamadas, o que leva a uma situação de falta de controle do fluxo de trabalho pelos operadores. Elas não encontram tempo suficiente para se recuperarem, podendo originar, dessa forma, sobrecarga muscular estática, além de uma sobrecarga cognitiva. Essas dificuldades parecem configurar uma adversidade do processo de trabalho, para o qual os operadores não encontram saídas. Ao menos, não conseguimos identificar estratégias satisfatórias para lidar com estas situações.

Entretanto, identificamos saberes e estratégias que ajudam Eunice a enfrentar outras adversidades. Todas apontam a necessidade das trabalhadoras ampliarem a possibilidade de uso de sua experiência. Percebemos isso quando ela decide chegar antes do horário, quando opta por sair ou seguir o script, quando cria expressões verbais, e quando se apóia nas ECRP para evitar erros. Podemos afirmar que sem o uso que elas fazem do tempo, do script, de suas expressões verbais e da relação com os demais trabalhadores, suas atividades de trabalho no call center se tornariam ainda mais desgastantes e dificilmente se alcançaria os resultados esperados. Abrahão, Sznelwar e Mascia (2006) questionam se as diferentes estratégias desenvolvidas pelos trabalhadores das centrais de atendimento seriam suficientes para que reduzam ou eliminem o sofrimento relacionado com o seu trabalho. Ou até mesmo se seria possível elaborar estratégias que permitam avanços significativos no que diz respeito aos resultados do trabalho, trazendo mais satisfação para eles e também para os clientes.

As estratégias encontradas nos parecem mais próximas dos mecanismos de defesa psíquica mostrados nos estudos clássicos de psicopatologia do trabalho (Dejours, 1987), que seriam mais estratégias de sobrevivência e que resultariam numa redução do nível de consciência e de reflexão sobre o problema. (Abrahão, Sznewar \& Mascia, 2006, p. 110).

Temos que ter todo cuidado com afirmações desse tipo. Oddone, Re e Brianti (1981) chamavam a atenção para o fato de que a cultura científica dominante, mesmo as concepções mais críticas, não contavam com um modelo positivo de trabalhador, como produtor atual, não futuro, capaz de refletir sobre sua condição de explorado e de produzir respostas ao nível da consciência individual ou do pequeno grupo.

Segundo Brito, Athayde e Neves (2003), a discussão sobre as estratégias e formas de enfrentamento no trabalho é importante porque nos orienta no esforço de compreensão do que está acontecendo afirmativo da vida ou a ela reativo, ajudando na luta para mudar o que se revela necessário. Precisamos analisar as formas de enfrentamento que 
são utilizadas. Algumas vezes são modos de enfrentamento equivocados que podem levar ao adoecimento. Podemos observar, por exemplo, na cena 7 (o peso do instante) que Eunice usa a expressão "preguiça de falar" como uma forma de eufemizar seu cansaço, originado por um resfriado. $\mathrm{Na}$ falta de poder vencer a rigidez da organização do trabalho, Eunice utiliza-se de um procedimento defensivo que não muda a realidade de imediato. Mesmo considerando as defesas como uma forma de criação humana, não podemos nos confundir e esquecer que se trata de um tipo de criação escorregadia. Precisamos observá-las com muito cuidado, porque, às vezes, escondem os problemas, dificultando uma ação preventiva ou uma mudança. $O$ excesso de reações de defesa de um organismo pode funcionar, paradoxalmente, como um aliado do fator agressor.

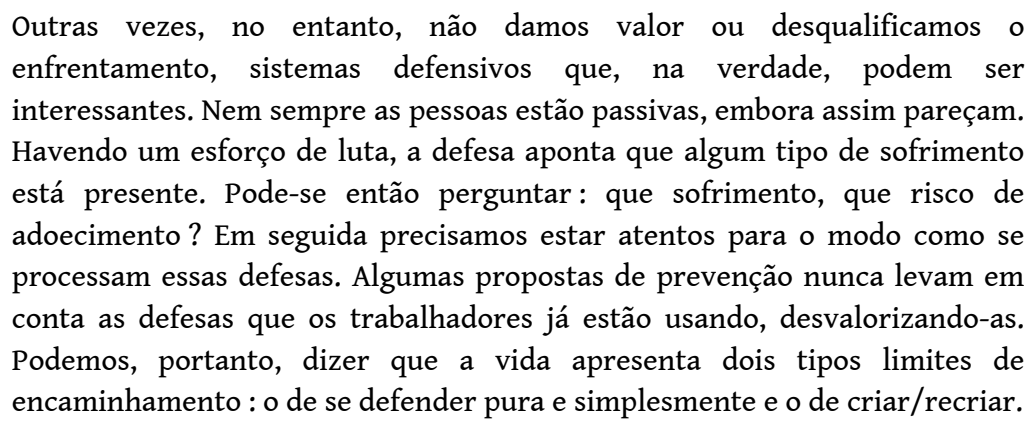

67 Eunice muitas vezes fala de seu trabalho como algo que a estimula, que desenvolve sua inteligência, sua habilidade : amor por este trabalho, mas "eterno enquanto dure" [3], pois Eunice pretende mais adiante partir para outra atividade profissional. Parece que a predeterminação dos tempos e de sua fala, que é um fator de múltiplas adversidades, não a faz reclamar sobre seu destino, mas ao contrário, a impulsiona, junto com seus colegas, a tirar melhor proveito das situações. É uma luta dura, contínua, que é vivida como um jogo que se joga sempre para ganhar e não para perder. Feitas as ressalvas, o que não podemos é perder de vista que a presença de sistemas defensivos - sejam ideológicos ou estratégicos, usando categorias criadas por Dejours - expressam que já está em curso um movimento de combate à fonte de sofrimento. E é desse desafio que devemos partir para a análise e as mudanças, tendo como norte a afirmação da vida e da saúde.

\section{BIBLIOGRAFIA}

Abrahão, J.I., Sznelwar, L.I., \& Mascia, F.L. (2006). Trabalhar em centrais de atendimento : a busca de sentido em tarefas esvaziadas. Revista Brasileira de Saúde Ocupacional, 31 (114), 97-112.

Associação Brasileira de Telesserviços (ABT) (2006). Retirado em fevereiro, 7, 2006, de http:// www.abt.org.br/6_pesquisa_abt.htm

Assunção, A.A., et al. (2006). Abordar o trabalho para compreender e transformar as condições de adoecimento na categoria dos teleatendentes no Brasil. Revista Brasileira de Saúde Ocupacional, 31

(114) : 47-62 
Athayde, M. (1996) Gestão de coletivos de trabalho e modernidade. [Tese de Doutorado em Engenharia]. Rio de Janeiro : COPPE/UFRJ.

Athayde, M. (2006) Uma proposta de orientação epistemológica, teórica e metodológica para a pesquisaintervenção no campo do trabalho humano do ponto de vista da atividade e da dialogia. Texto para discussão. Rio de Janeiro : Programa de Pós-Graduação em Psicologia Social/UERJ, 2006 (mimeo.).

Balka, E. (1995) Technology as a factor in women's occupational stress: the case of telephone operators. In K. Messing, B. Neis, Dormais. Invisible, La santé des travailleuses. Canadá: Gynergy Books,

Brito, J. \& Athayde, M. (2003). Trabalho, educação e saúde : o ponto de vista enigmático da atividade. Trabalho Educação e Saúde, v. 1 , n 2

Brito, J., Athayde, M. \& Neves, M. Y. (orgs.) (2003). Caderno de textos : programa de formação em saúde, gênero e trabalho nas escolas. João Pessoa : Editora Universitária/UFPB.

Buscatto, M. (2002). Les Centres d'appels, usines modernes ? Les rationalisations paradoxales de la relation teléphonique. Sociologie du travail, 44, 99-117.

Canguilhem, G. (2001). Meios e normas do homem no trabalho. Pro-posições, v12, n. 2-3.

Canguilhem, G. (2006). o normal e o patológico. Rio de Janeiro :Forense Universitária, $6^{a}$ ed.

Clot, Y. (1999). Ivar Oddone : les instruments de l'action. Les territoires du travail, 3, pp. 43-51.

Clot, Y. (2006). A função psicológica do trabalho. Petrópolis : Vozes.

Cru, D. (1985). Langage de métier chez les tailleurs de pierre. Travail, n.6, p. 48-55.

Cru, D. (1987a).Les règles du métier. In C. Dejours (org.) Plaisir et souffrance dans le travail. Paris : AOCIP, p. 29-42

Cru, D. (1987b). Collectif et travail de métier. In C. Dejours (org.) Plaisir et souffrance dans le travail. Paris : AOCIP, p. 42-50.

Cru, D. (1995). Règles de métier, langue de métier : dimension symbolique au travail et démarche participative de Prévention Le cas du Bâtiment et des travaux publics, Diplôme de l'École Pratique des Hautes Études.

Cru, D. \& Dejours, C. (1987). Saberes de Prudência nas Profissões da Construção Civil : Nova contribuição da Psicologia do Trabalho à análise da prevenção de acidentes na Construção Civil. Revista Brasileira de Saúde Ocupacional, vol. 15, nº 59, 30-34.

Dejours, C. (1993). Coopération et construction de l'identité en situation de travail. Futur Antérieur n.16, pp. 41-52.

Dejours, C. (1994). Itinerário teórico em Psicopatologia do Trabalho. In : Dejours C ; Abdoucheli E, Jayet C. Psicodinâmica do trabalho. São Paulo : Atlas.

Dejours, C. (2004). Subjetividade, trabalho e ação. Revista Produção, v. 14, n. 3, p. 27-34, Set./Dez.

Dejours, C. (2008a) Inteligência prática e sabedoria prática. In S. Lancman \& L. Snelwar (Orgs). Christophe Dejours : da psicopatologia à psicodinâmica do trabalho. Rio de Janeiro : Editora Fiocruz, $2^{\mathrm{a}} \mathrm{ed}$.

Dejours, C. (2008b). Travail, usure mentale. Paris: Bayard Centurion, $5^{\mathrm{a}}$ ed.

Di Ruzza, R. \& Franciosi, C. (2002). Situations de travail dans les centres d'appels telephoniques. Paris : Institut Syndical d'Etudes et de Recherches Economiques et Sociales.

Faïta, D. (2005). Análise Dialógica da Atividade Profissional. Rio de Janeiro : Imprinta Express. 
Fernandes, S.R., Di Pace, D.M.T. \& Passos, M.F.D. (2002). Organização e condições de trabalho em "telemarketing" : repercussões na saúde psíquica dos trabalhadores. In M.G. Jacques \& W. Codo (orgs). Saúde mental e trabalho : leituras. Petróplis : Vozes.

Gallais, S.(1999). Les Centres d'appels. Aix-en-Provence : Departement d'Ergologie - APST, Université de Provence.

Le Guillant, L. et al. (1956/1984) A neurose das telefonistas. Revista Brasileira de Saúde Ocupacional, v. 12, n.47, p. 7-11, jul./ag./set.

Marinho-Silva, A. (2004). Regulamentação das condições de trabalho no setor de teleatendimento no Brasil : necessidades e desafios. [Dissertação de Mestrado] do Programa de Pós Graduação em Saúde Pública da Faculdade de Medicina da UFMG, Belo Horizonte.

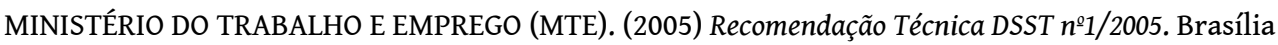
23 mar.. <www.mte.gov.br/Empregador/segsau/Legislacao/Recomendacoestecnicas/Conteudo/ recomendacaotecnica012005.pdf>. Acesso em 7 fev.2006

Oddone, I., Re, A. \& Brianti, G. (1981). Redécouvrir l'expérience ouvrière. Paris : Eds. Sociales.

Peres, C.C. (2003) Avaliação da satisfação com o sistema de pausas no trabalho de teleatendimento/ telemarketing. [Dissertação de Mestrado em ergonomia] Porto Alegre : Escola de Engenharia da UFRGS. Disponível em http:// www.producao.ufrgs.br/ Banco_teses>.

Santos, V. C. (2004). As múltiplas tarefas e atividades Interferentes em centrais de atendimento telefônico. Revista Brasileira de Saúde Ocupacional, 29 (109), 21-29.

Segnini, L. (2001). Relações de gênero e racionalização do trabalho em serviços de atendimento a distância. In: Salerno (org). Relação de serviço : produção e avaliação. pp 152-181. São Paulo : Editora SENAC.

Schwartz, Y. (2000a). Trabalho e uso de si. Pro-posições. no.32.

Schwartz, Y. (2000b). Le paradigme ergologique ou um métier de Philosophe. Toulouse :Octarès.

Schwartz, Y. (2007a). O trabalho e o uso de si. In Y. Schwartz e L. Durrive (orgs.) Trabalho e Ergologia : conversas sobre a atividade humana. Niterói: EdUFF.

Schwartz, Y. (2007b). Anexo ao Capítulo 5 : A dimensão coletiva do trabalho, as “ ECRP ». In Y. Schwartz e L. Durrive (orgs.) Trabalho e Ergologia : conversas sobre a atividade humana. Niterói : EdUFF.

Silva E.F., Brito, J., Neves, M.Y. \& Athayde, M. (2009). A Promoção da Saúde a partir das situações de trabalho : considerações referenciadas em uma experiência com trabalhadores de escolas públicas. Interface - Comunicação, Saúde, Educação, v.13, n.30, jul./set. 2009.

Toomingas, A. et al. (2002). Work condititions and employee health at call centers. Sweden: Departament of Occupational Medicine, Sundsvall Hospital.

Torres, C.C. (2001). A Atividade nas Centrais de Atendimento : Outra Realidade, as Mesmas Queixas. [Dissertação de Mestrado] Brasília : Instituto de Psicologia da UNB,

Vasconcelos, R. \& Lacomblez, M. (2005). Redescubramo-nos na sua experiência : O desafio que nos lança Ivar Oddone. Laboreal, 1, (1), 38-51. http://laboreal.up.pt/revista/artigo.php? id=37t45nSU547112358941523351

De Vincenti (1999). Ivar Oddone, intelectuel organique et chercheur hétérodoxe. Les territoires du travail, 3, pp. 33-42. 
Vilella, L. \& Assunção, A. (2004). Os mecanismos de controle da atividade no setor de teleatendimento e as queixas de cansaço e esgotamento dos trabalhadores. Cadernos de Saúde Pública, vol. 20, no.4, p. 1069-1078, jul./ago.

Zarifian, Ph. (2002). Le travail dans un centre d'appel. Retirado em Janeiro, 7, 2006, de http:// perso.wanadoo.fr/philippe.zarifian/.

\section{NOTAS}

1. Esta foi uma situação peculiar, pois o pesquisador que conduziu a conversa e fez uso da técnica, já havia trabalhado como operador de telemarketing no mesmo setor que Eunice. Representava assim nesse diálogo um híbrido : ex-colega de trabalho e ao mesmo tempo pesquisador, como se pode notar ao longo do diálogo.

2. Suponha que eu seja teu sósia e amanhã eu o substitua (...)".

3. Verso contido em poema de Vinícius de Moraes.

\section{RESUMOS}

Em um estudo exploratório buscou-se compreender as atividades de operação de telemarketing em uma central de atendimento de grande porte e as relações com a saúde dos operadores. Os referenciais mais gerais utilizados foram a concepção vitalista de Canguilhem e a perspectiva ergológica, incorporando ferramentas teórico-metodológicas de abordagens clínicas do trabalho, como a Psicodinâmica do Trabalho e a Clínica da Atividade. A 'entrevista' realizada inspirou-se na técnica de "instruções ao sósia". Percebeu-se que a maioria das situações adversas enfrentadas no trabalho é relativa ao estabelecimento de um "tempo médio de atendimento" que deve ser cumprido independente do tipo de cliente e de situação. Entretanto, percebemos que sem o uso que os operadores fazem do tempo, do script, de suas expressões verbais e da relação com os demais trabalhadores, as atividades de trabalho no call center se tornaria ainda mais desgastante, e dificilmente se alcançariam os resultados esperados.

Este estudio exploratorio buscó comprender la actividad de operación de telemarketing y sus relaciones con la salud de los operadores en una central de atención de gran porte. Los referentes teóricos utilizados fueron la concepción de vida y salud en la obra de Canguilhem y la perspectiva ergológica, incorporando herramientas teórico-metodológicas de abordajes clínicos del trabajo, como la Psicodinámica del Trabajo y la Clínica de la Actividad. La "entrevista" realizada fue inspirada en la técnica de "instrucciones al doble". Percibimos que la mayoría de las situaciones adversas enfrentadas en el trabajo es relativa al establecimiento de un tiempo medio de atención que debe ser cumplido independientemente del tipo de cliente y de la situación. Entretanto, observamos que sin el uso que los operadores hacen del tiempo, del script, de sus expresiones verbales y de la relación con los demás trabajadores, la actividad de trabajo en el call center se tornaría más desgastante y difícilmente se alcanzarían los resultados esperados.

Cette étude exploratoire à voulu comprendre les activités de l'opération de télémarketing dans un grand centre d'appel et ses relations avec la santé des opérateurs. Les référentiels théoriques utilisés sont ceux de la conception de la vie et de la santé propre à l'œuvre de Canguilhem, ainsi 
que la perspective de l'ergologie. Mais sont repris également des outils théoricométhodologiques de certaines approches cliniques du travail, à savoir : de la Psychodynamique du Travail et de la Clinique de l'activité. L'" entretien " réalisé fut inspiré de la technique des “instructions au sosie ». On a constaté que la majorité des situations critiques sont en relation avec le fait qu'un temps moyen d'appel a été établi et doit être respecté indépendamment du type de client et de la situation. On a cependant observé que, si les opérateurs ne redéfinissaient pas temps, script, expressions verbales et relation avec les autres travailleurs, leur activité du travail au centre d'appel serait plus éprouvante encore et permettrait difficilement d'obtenir les résultats souhaités.

The aim of this explorative study was to understand the activities of operators in a large telemarketing call center and the relationship of this work to their health. The general theoretical references used were the concepts of life and health as seen in the work of Canguilhem and the ergological perspective, incorporating theoretical and methodological tools of clinical approaches to work, such as the Psychodynamics of Work and the Clinic of the Activity. The "interview" conducted was inspired by the technique of "instructions to the double". It was noted that the most adverse situation faced by telemarketers at work is that related to the establishing of an average service time which must be met regardless of the type of client and situation. However, we realize that without the use that workers make of their time. the script, their verbal expressions and relationships with other workers, the work activity at the call center would be even more destructive and they would hardly ever reach the expected results.

\section{ÍNDICE}

Palavras-chave: teleatendimento, atividade de trabalho, saúde do trabalhador, setor de serviços, instrução ao sósia

Palabras claves: teleatendimiento, actividad de trabajo, salud del trabajador, sector de servicios, instrucción al doble

Mots-clés: télémarketing, activité de travail, santé du travailleur, secteur des services, instruction au sosie

Keywords: telemarketing, work activity, worker's health, services, instructions to the double

\section{AUTORES}

\section{MARCELLO SANTOS REZENDE}

Mestre em Saúde Pública, Psicólogo da Eletrobrás (Centrais Elétricas Brasileiras S.A.), Av.

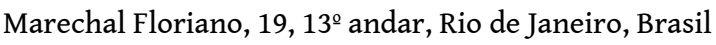

marcellosantosr@gmail.com

\section{JUSSARA BRITO}

FIOCRUZ - Escola Nacional de Saúde Pública, Rua Leopoldo Bulhões 1480, Rio de Janeiro, Brasil jussara@ensp.fiocruz.br 


\section{MILTON ATHAYDE}

Universidade do Estado do Rio de Janeiro - Pós-Graduação em Psicologia Social, Rua São Francisco Xavier 524, sala 10.009, bloco F, Maracanã, Rio de Janeiro, Brasil

athayde.milton@gmail.com 